\title{
Structural Geology of the Basement Complex Rocks in Iwaraja Area, Southwestern Nigeria
}

\author{
Blessing Adeoti ${ }^{1, * a}$ and Chukwuemeka Tony Okonkwo ${ }^{2, b}$ \\ ${ }^{1,2}$ Department of Applied Geology, Federal University of Technology Akure. P.M.B 704, Akure, \\ Nigeria.

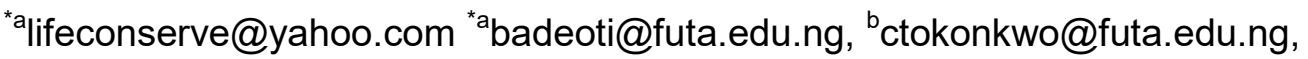

Keywords: Shear zone, Mylonite, Iwaraja, Pan-African orogenesis, late-Precambrian

\begin{abstract}
The geological and structural evolution assessment of the Basement Complex rocks in Iwaraja area, southwestern Nigeria showed that the basement rocks comprise quartzites and quartzschists of the Effon Psammite Formation, quartz-mica schists, biotite schists, migmatitic gneisses, granitic gneisses, late and post-tectonic granitic rocks including pegmatites, which have been subjected to two phases of deformation. The first phase is mainly a fabric forming deformation that also led to the development of moderately plunging mineral lineation. No minor fold of this phase was recognized. The second deformation phase gave rise to the development of Iwaraja (ductile) shear zone. The mylonitic foliation is sub-vertical and steeply dipping and while the mineral lineation is sub-horizontal and shallowly plunging. Within granitic gneiss mylonites, the shear zone is characterised by early and late open to tight folds of pegmatite dykes. Adjacent the shear zone, ptygmatic folds of quartzo-feldspathic veins in gneisses and crenulated cleavages that overprinted earlier schistosity surfaces in the quartz-mica schist also characterised this deformation phase. Extensional fractures in the various lithologies generally show bimodal orientations mainly in the WNW-ESE and NW-SE directions, which are nearly perpendicular to the regional metamorphic foliations. These deformation conditions depict structural features that are associated with internal zones of orogenic belts. Within the study area, the structures document late-Precambrian deformation during the closing stages of Pan-African orogenesis.
\end{abstract}

\section{Introduction}

The Iwaraja area constitutes part of the Ilesha schist belts in southwestern part of the Nigerian Basement Complex, a part of the African crystalline shield. This particular schist belt has been recognized as a Pan-African ensialic mobile belt derived from an aulacogen, and is connected with the ocean [1]-[4]. The basement complex rocks of Iwaraja area represent one of the important areas in understanding late stages of the Pan-African orogeny $(600 \pm 150 \mathrm{Ma})$ within the southwestern Nigerian. The basement rocks of this area bear distinct manifestations of late-Precambrian deformation. The study area adjoined the Ifewara transcurrent fault system to the east of Ilesha Schist Belt within the southwestern Nigerian Basement Complex.

Studies [e.g. 5-8] have shown that the Nigerian Basement Complex comprises Archean and Proterozoic rocks and bears the imprints of the Liberian $(2700 \pm 200 \mathrm{Ma})$, Eburnean $(2000 \pm$ $200 \mathrm{Ma}$ ) orogenic events. This basement was a zone of reactivation and orogenesis during the PanAfrican (600 $\pm 150 \mathrm{Ma})$ event $[9,10]$. Regionally, the basement complex of Nigeria represents the southern part of the Trans-Saharan mobile belt [11]-[14]. According to [15], the Trans-Saharan Belt is more than $3000 \mathrm{~km}$ long and occurs to the north and east of the West African Craton within the Anti-Atlas and bordering the Tuareg and Nigerian shields.

The belt consists of pre-Neoproterozoic basement strongly reworked during the Pan-African event and of Neoproterozoic oceanic assemblages. The link between the Nigeria Shield and the Trans-Saharan Belt has offered more insight into the evolution of the basement. Geological and geophysical evidences from the western province of the Trans-Saharan belt and the cratonic margin have been used to erect geodynamic models for the evolution of the belt $[14,16,17]$. The evolution of the belt is seen as a collision-type orogeny with an eastward-dipping subduction zone. Evidence 
from the eastern and northern margins of the West African craton indicates that the Pan-African belt which has affected the Nigerian Basement Complex as a result of the collision between the passive continental margin of the West African Craton and the active continental margin (Pharusian belt) of the Tuareg Shield about 600Ma ago (Fig. 1).

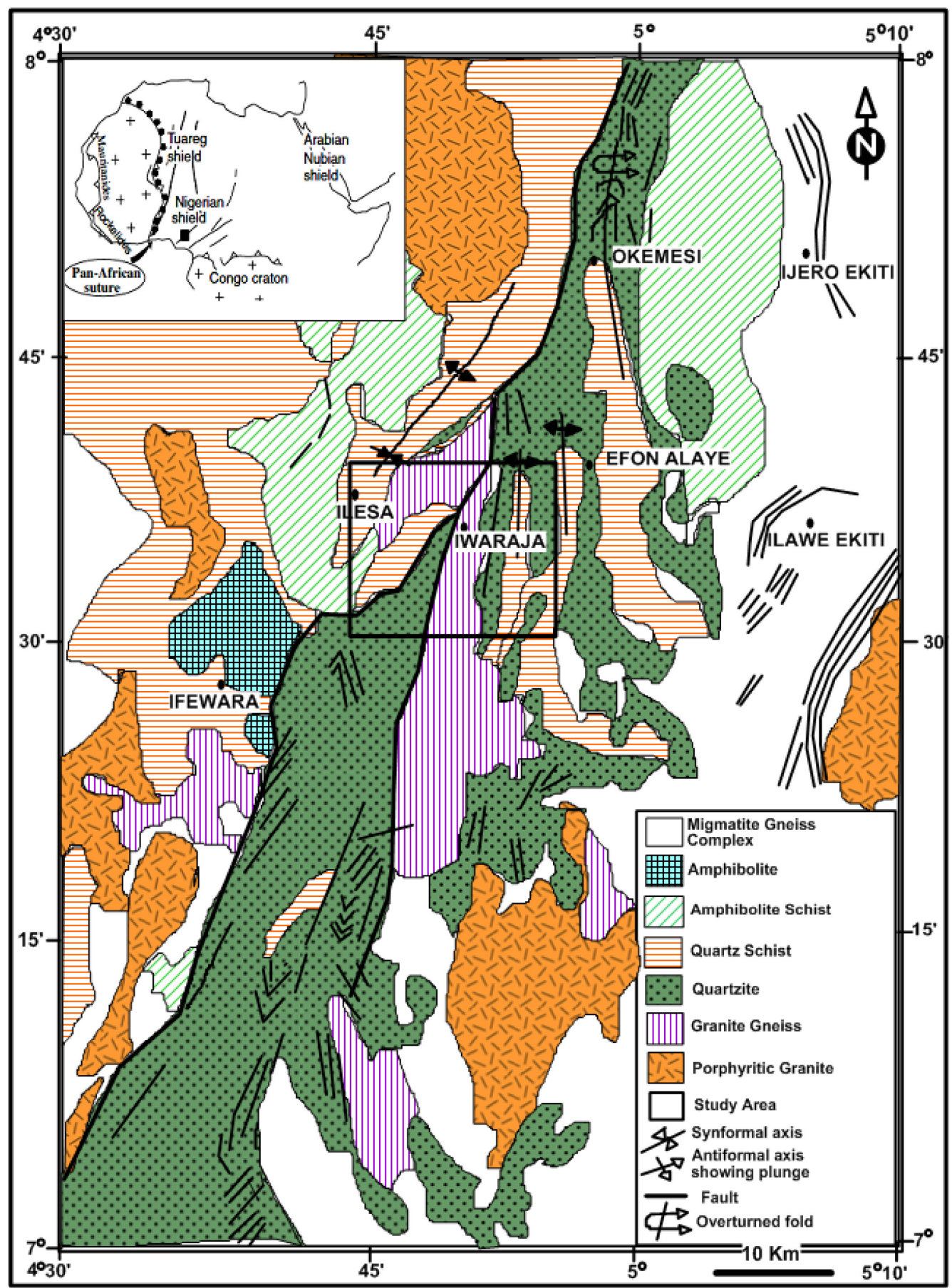

Fig. 1. Regional geological sketch map of the study area within the framework of the Hoggar-AirNigeria province (Modified from [13]).

Continental-scale shear zones within the Trans-Saharan belt have been correlated with this study area $[11,12]$. It is therefore important that the detailed geological and structural assessment of the evolution of the basement complex rocks in the Iwaraja area be carried out, which will help to understand deformation activities in the southwestern Nigerian segment of the Pan-African orogenesis. This paper documents the results of our recent studies that were carried out in the Iwaraja area and discusses the geology and structural development of the basement rocks in the area. 


\section{Materials and Methods}

Landsat $7(\mathrm{ETM}+)$ of the study area was processed and integrated with detailed geological field mapping to discriminate lithologies and structural lineaments. Detailed structural mapping was systematically carried and forty-eight (48) thin sections were prepared from selected rock samples for petrographic study.

\section{Results and Interpretation}

\subsection{Lineaments}

The analysis of the satellite image (Landsat $7 \mathrm{ETM}+$ ) of the study area is shown in Fig. 2 and plot of the azimuth frequency of lineaments (Table 1) shows general orientation in NNE-SSW direction.

Table 1. Azimuth frequency of lineaments from the Landsat Image of the Iwaraja area

\begin{tabular}{|l|l|l|}
\hline Azimuth & $\mathrm{N}$ & $\mathrm{N} \%$ \\
\hline $0-20$ & 23 & 50 \\
\hline $21-40$ & 12 & 26.09 \\
\hline $41-60$ & 3 & 6.52 \\
\hline $61-80$ & 1 & 2.17 \\
\hline $81-100$ & 0 & 0 \\
\hline $101-120$ & 0 & 0 \\
\hline $121-140$ & 0 & 0 \\
\hline $141-160$ & 0 & 0 \\
\hline $161-180$ & 7 & 15.22 \\
\hline$\Sigma$ & 46 & 100 \\
\hline
\end{tabular}

\subsection{Geology of Iwaraja area}

The Iwaraja area (Fig. 3) is underlain by metasedimentary and metaigneous rocks which have been intruded by late to post-tectonic granitic rocks of probable Pan-African age. As a result of polyphase deformation, the lithostratigraphic sequence is difficult to establish with certainty. However, the distribution and mode of field occurrences of the lithologies and structural (including cross-cutting) relationships are discussed in this study.

\subsubsection{Migmatitic Gneiss}

This lithological unit (Fig. 4a-c) crops out in the northeastern parts of the study area occurring as steeply rising outcrop. It is a leucocratic, medium-grained, weakly foliated rock. The gneissic foliation is defined by series of alternation of dark and light-coloured bands of mafic and felsic minerals respectively. The mineralogy of the migmatitic gneiss comprises plagioclase (35\%), microcline $(26 \%)$, quartz $(23 \%)$, biotite $(13 \%)$ and opaque minerals $(3 \%)$. Microcline grain size is between $0.5-1 \mathrm{~cm}$, biotite is $0.2-0.4 \mathrm{~cm}$ along the long axes. It is cut by varying bands of late-post tectonic pegmatite veins. 

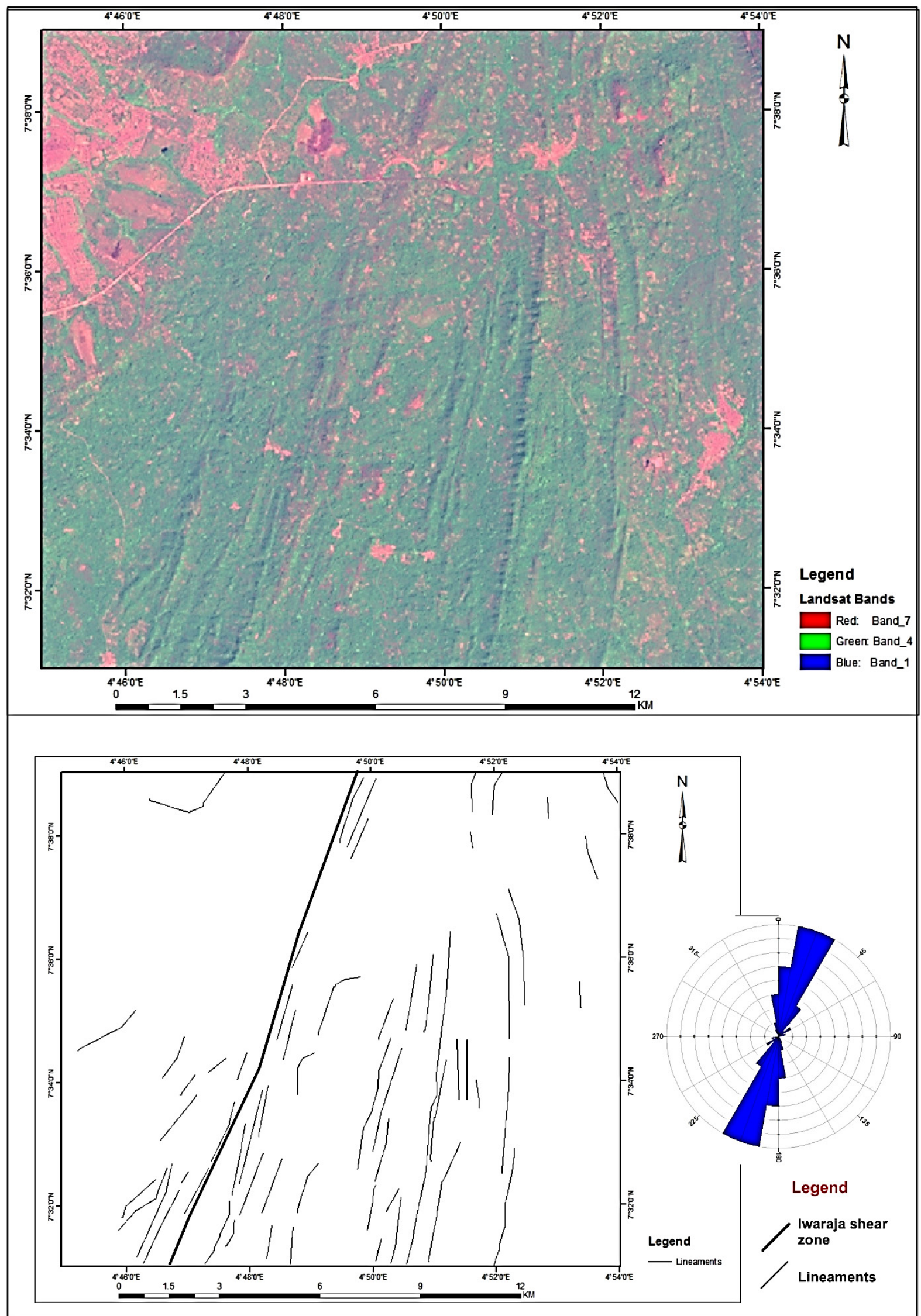

Fig. 2. Lineaments extracted from Landsat $7(\mathrm{ETM}+)$ of the Iwaraja area. The orientation of the lineaments is shown in the rose diagram plot, which trends in the NNE-SSW direction. 


\subsubsection{Granitic Gneiss}

This unit (Fig. 4d-f) occurs as low-lying to moderately-rising outcrops. It crops out mainly in the central part of the study area with a general NE-SW orientation. It is a leucocratic, with a medium to coarse-grained texture and possessing moderate to strong foliation. These foliations are defined by grain alignment of elongate feldspars (especially pinkish K-feldspars) and quartz with segregated thin layers of biotite. The grain sizes of plagioclase and microcline vary from mediumgrained in the southern to coarse-grained in the northern part of the study area. Grain size of pinkish microcline along long axes varies from $0.5-1 \mathrm{~cm}$; in biotite, it is $0.2-0.4 \mathrm{~cm}$ while in quartz, it is $0.2-0.5 \mathrm{~cm}$. The granitic gneiss is also locally marked by mineral lineation, defined by grain shape of quartz and feldspar. In most of the granitic gneiss outcrops, veins of quartzo-feldspathic composition and pegmatite dykes cut concordantly with the granitic gneiss foliations. Some of the veins have been folded and they have their fold axes in the same direction as the gneissic bands. The thickness of these veins range from $0.4-13.2 \mathrm{~cm}$. Generally, the mineralogy of the granitic gneiss comprises microcline (34\%), plagioclase $(22 \%)$, quartz $(21 \%)$, biotite $(12 \%)$ and opaque mineral (1\%). Photomicrographs of the unsheared and sheared granitic gneiss are shown in Fig. 5.

\subsubsection{Quartzite}

This lithology (Fig. 4 g-h) occurs as ridges (NE-SW lineament orientation) in the eastern part and mostly as low-lying outcrops in few places in the western part of the study area. The texture of this rock unit shows reduction in grain size towards the ductile shear zone. The petrographic study showed that this lithologic unit consists of quartz with muscovite and sillimanite. This mineralogy is not generally homogenous. Where the mineralogy is not essentially quartz, it comprises muscovite and sillimanite. The occurrence of muscovite increases towards the shear zone while sillimanite decreases towards it. In the northern part of the study area, the mineralogy comprises mainly quartz. Sillimanite is common in the outcrop at the eastern part of the study area particularly in the outcrops at Erinmo and also the southern part of Erin-Odo. The occurrence of muscovite is common in outcrops at the western part of the study area. Quartz veins which have suffered some degree of deformation cut the lithology especially at Omogbara locality. Their thicknesses vary from $1-4 \mathrm{~cm}$.

\subsubsection{Quartz Schist}

This lithology (Fig. 4i) is widespread, although intensely weathered in most places, but roadcuts and some few low-lying outcrops along stream channels provided good sections where the lithology could be clearly examined. It out crops mainly at the foot of quartzite ridges and in some places, it forms thick interbedded unit with the quartzite. It is also strongly foliated. The schistosity is defined by the alignment of the platy minerals dominantly muscovite. The mineralogy comprises quartz $(73 \%)$, and muscovite $(27 \%)$.

\subsubsection{Quartz-Mica Schist}

This rock (Fig. 4j-k) crops out in the southwestern part of the study area as low-lying outcrops predominantly around Arubu and Ijemba, Ilu-Olomo and Ile-Igbo localities (Fig. 3). It is mediumgrained in texture and petrographically different from the quartz schist by the relatively abundance of biotite and garnet. It is variously intruded by quartz veins of $0.3-13.1 \mathrm{~cm}$ thickness and also intensely weathered, which limited thorough examination of the rock. The mineralogy comprises quartz $(54 \%)$, biotite $(31 \%)$ and garnet $(15 \%)$. 

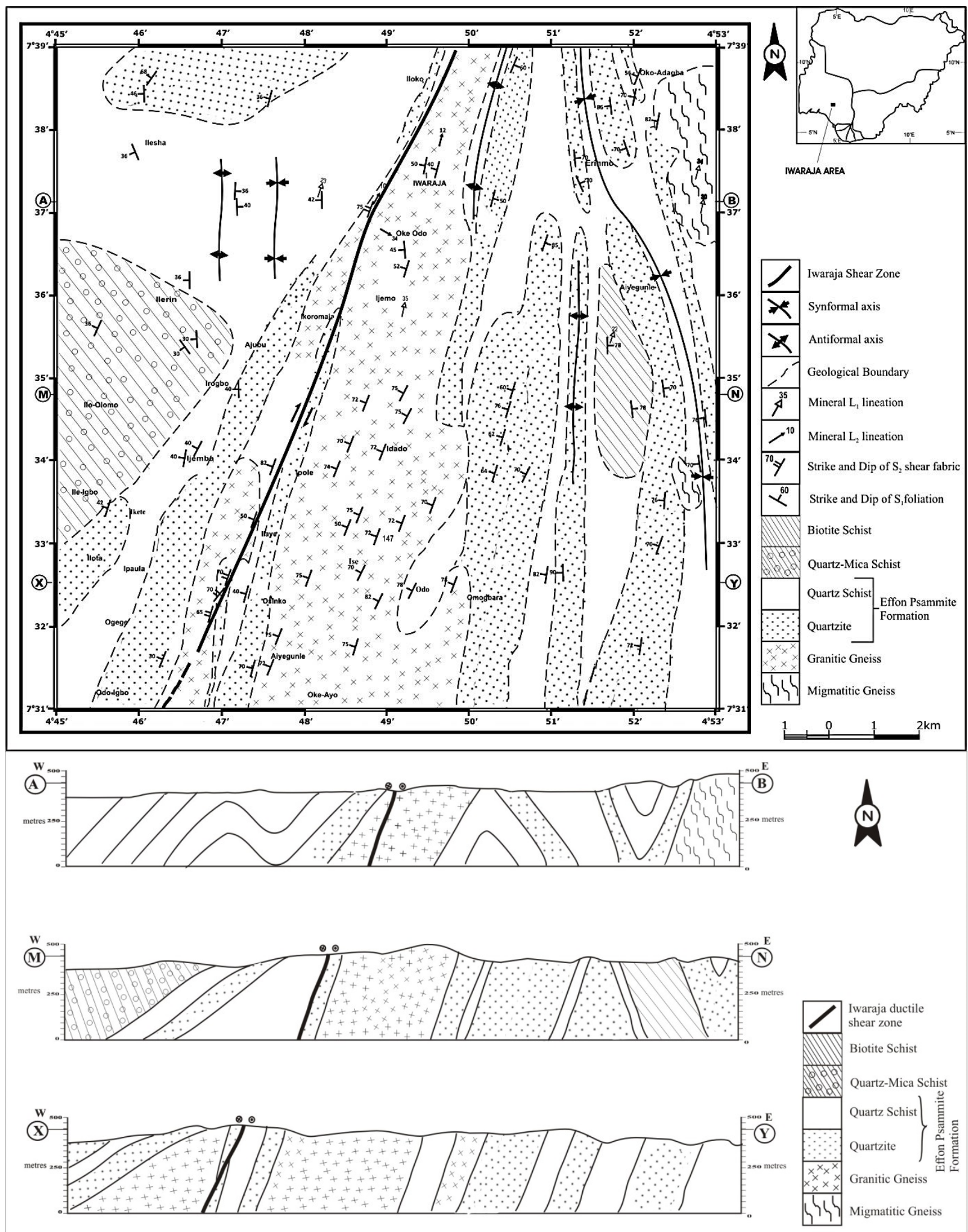

Fig. 3. Geological map and cross-sections across three traverses in the Iwaraja area (after [18]). 

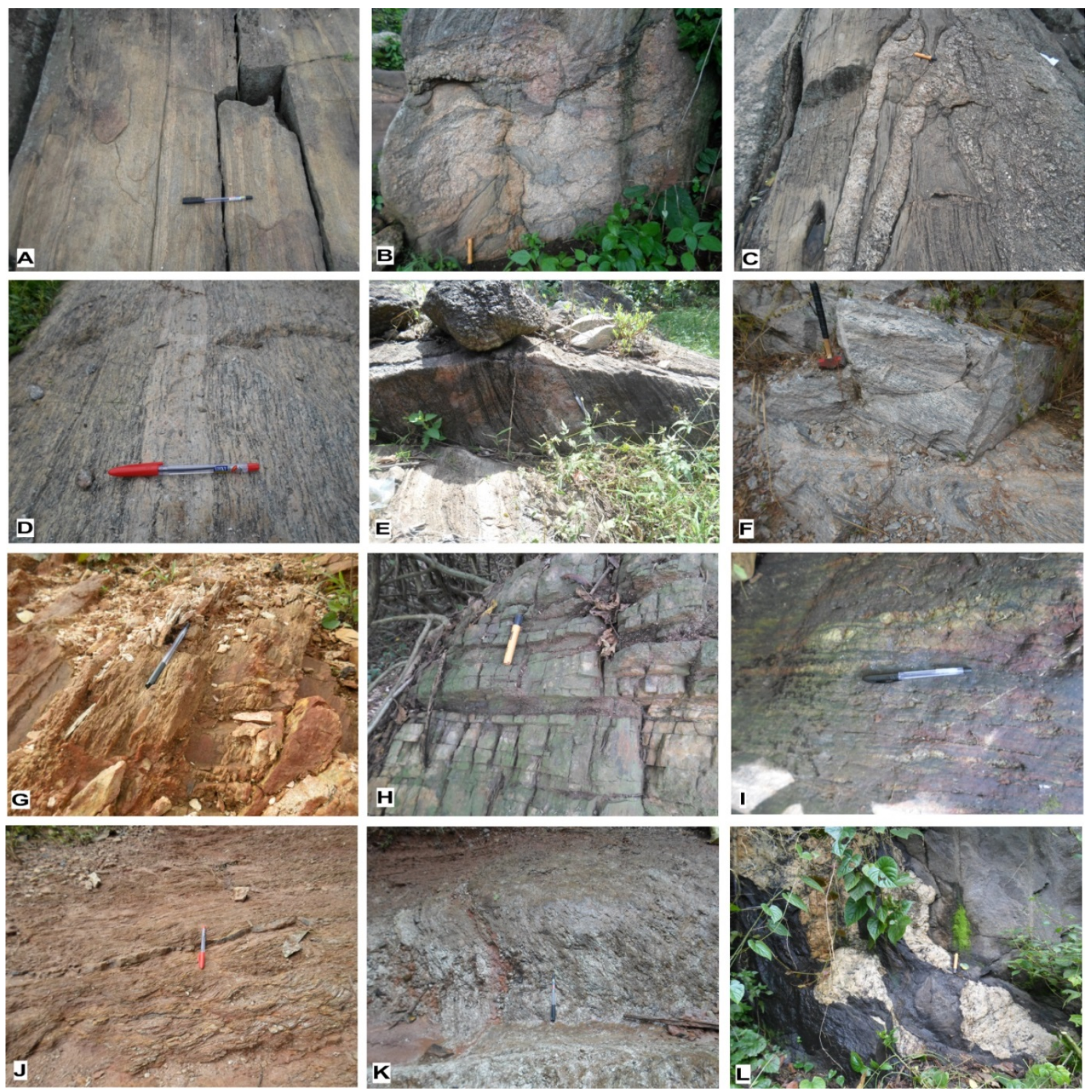

Fig. 4. Photographs of mode of occurrences of the lithological units (a) migmatitic gneiss with fabric defined by series of thin compositional layers of felsic and mafic minerals and also showing sequence of folded pegmatite bands cutting into the gneiss at Erimo-Ijesa (b) a portion showing sequence of pegmatite bands cutting into the gneiss (c) a section through a portion of the gneiss showing relicts of gneiss leucosomes within pegmatite (d) strong foliation, defined by augen-shaped pink k-feldspars in the granitic gneiss at Iwaraja (e) steeply dipping granitic gneiss at Ise (f) granitic gneiss outcrop adjacent the shear zone, showing gneissic bands $(\mathrm{g})$ weathered road-cut outcrop of quartzite along Ijeda-Erinmo road $(\mathrm{h})$ offshoot of quartzite in the quartzite ridges around OmoIjesha (i) low-lying outcrop of quartz schist at Omogbara (j) quartz schist outcropping along IlerinIrogbo road (k) moderately dipping, low-lying outcrop of quartz-mica schist along Ilo-Olomo Odogbo road (1) road-cut outcrop of biotite schist at Omo.

\subsubsection{Biotite Schist}

This lithological unit (Fig. 41) crops out mainly at the eastern part of the study area with two major good exposures at road-cuts around Omo-Aiyegunle locality. It occurs mainly as low-lying outcrops along stream channels with medium-grained texture and strongly foliated. The schistosity is defined by the alignment of the biotite and hornblende. The mineralogy comprises biotite (38\%), quartz $(28 \%)$, hornblende $(19 \%)$, plagioclase $(10 \%)$, and muscovite $(5 \%)$. The rock is cut by pegmatite veins with thickness which ranges between $0.3-5 \mathrm{~cm}$. 


\subsection{Structural Development}

The metamorphic rocks of Iwaraja area have undergone polyphase deformation, which had led to the development of various metamorphic fabrics (foliations, lineations), folds, ductile shear zones and brittle structures. The two observed deformation phases that are recorded in the lithologic units are denoted as $\mathrm{D}_{1}$ and $\mathrm{D}_{2}$ and discussed under this section.

\subsubsection{First Deformation}

This deformation phase $\left(\mathrm{D}_{1}\right)$ is characterised by the development of a regional, steeply- to moderately-dipping foliation $\left(\mathrm{S}_{1}\right)$. These foliations are defined by the development of gneissic bands in the migmatitic- and granitic gneisses and by the development of schistosity, in the metasedimentary rocks (quartzite, quartz schist, quartz-mica schist, biotite schist) which is defined by the preferred orientation of platy minerals mainly biotite and muscovite. The dip angle of the planar surfaces is generally sub-vertical, with value ranging from $60^{\circ}-85^{\circ}$. The equal area stereographic projection of poles to foliations $\left(\mathrm{S}_{1}\right)$ shows that the fold axis plunges $06^{\circ}$ and trends $011^{\circ}$ (Fig. 7a). The later refolding of these surfaces causes variation in their dip orientations to the east and west, corresponding to NNE-SSW and NNW-SSE strike directions, which depicts the attitude of the major fold. This deformation phase also produces mineral lineation $\left(\mathrm{L}_{1}\right)$ that plunges to NNE direction at moderate angles, with mean value of $32^{\circ}$. The wide scattering of stereographic projections of $\left(\mathrm{S}_{1}\right)$ foliation (Fig. 6) depicts the attitude of the major fold and deformation activities. Since $D_{1}$ folds are not recorded or no record of overprinting, it is believed that this deformation phase is mainly a fabric forming events.

\subsubsection{Second Deformation}

The second deformation phase $\left(\mathrm{D}_{2}\right)$ is associated with the development of a major ductile shear zone, which has been identified as Iwaraja shear zone. The shear zone possesses very strong shear fabric in the affected rocks especially the granitic gneiss, with a steeply-dipping, NNE-SSW orientation and sub-vertical dip angles as well as sub-horizontal mineral lineation. The mylonite is characterised by protomylonitic to ultramylonitic shear fabrics. Asymmetrical and tight to isoclinal folds (Fig. 7a) were associated with the shear deformation. Structures associated and coeval with this phase of deformation outside the shear zone were also recognized. These structures include asymmetrical, tight to isoclinal and ptygmatic (Fig. 7d) minor folds of late post-tectonic pegmatite dyke. Intra-folial isoclinal folds were also recognized (Fig. 7b) in the migmatitic gneiss. In the biotite schist, structures such as asymmetrical, open folds of quartzo-feldspathic veins (Fig. 7c) while the granitic gneiss shows quartz bands which were deformed to produce asymmetrical and open to tight folds, that are axial planar to $\left(\mathrm{S}_{1}\right)$ foliations (Fig. $\left.7 \mathrm{e}, \mathrm{f}\right)$.

Late deformation structures include extensional strain deformations which produced boudinages of quartz bands in the granitic gneiss (Fig.7g). West of the shear zone, this deformation phase led to the development of crenulation cleavage on earlier $\left(S_{1}\right)$ schistosity locally observed in the quartz-mica schist at Arubu and Ilo-Olomo localities but absent in other parts of the quartz-mica schist, e.g. at Ile-Igbo towards Odo-Igbo localities. Major antiformal and synformal folds, recognized in cross-section (Fig. 3) are also the result of this late deformation phase that has affected the entire study area.

Brittle deformation in the lithological units are characterised by several joints sets (Table 2) that were observed in most of the outcrops. In the granitic gneiss, extensional joints cut perpendicularly to $\left(\mathrm{S}_{1}\right)$ surfaces and they are mostly set of parallel joints with a general orientation of WNW-ESE (Fig.8a). In the quartzite, intersecting joints and sets of parallel joint are common, having dominantly bimodal orientations of ESE-WNW and ENE-WSW (Fig.8b). In the quartz-mica schist, joint orientation is in NW-SE direction (Fig.8c) while bimodal orientations of NW-SE and WNW-ESE were depicted in the quartz schist (Fig.8d). 

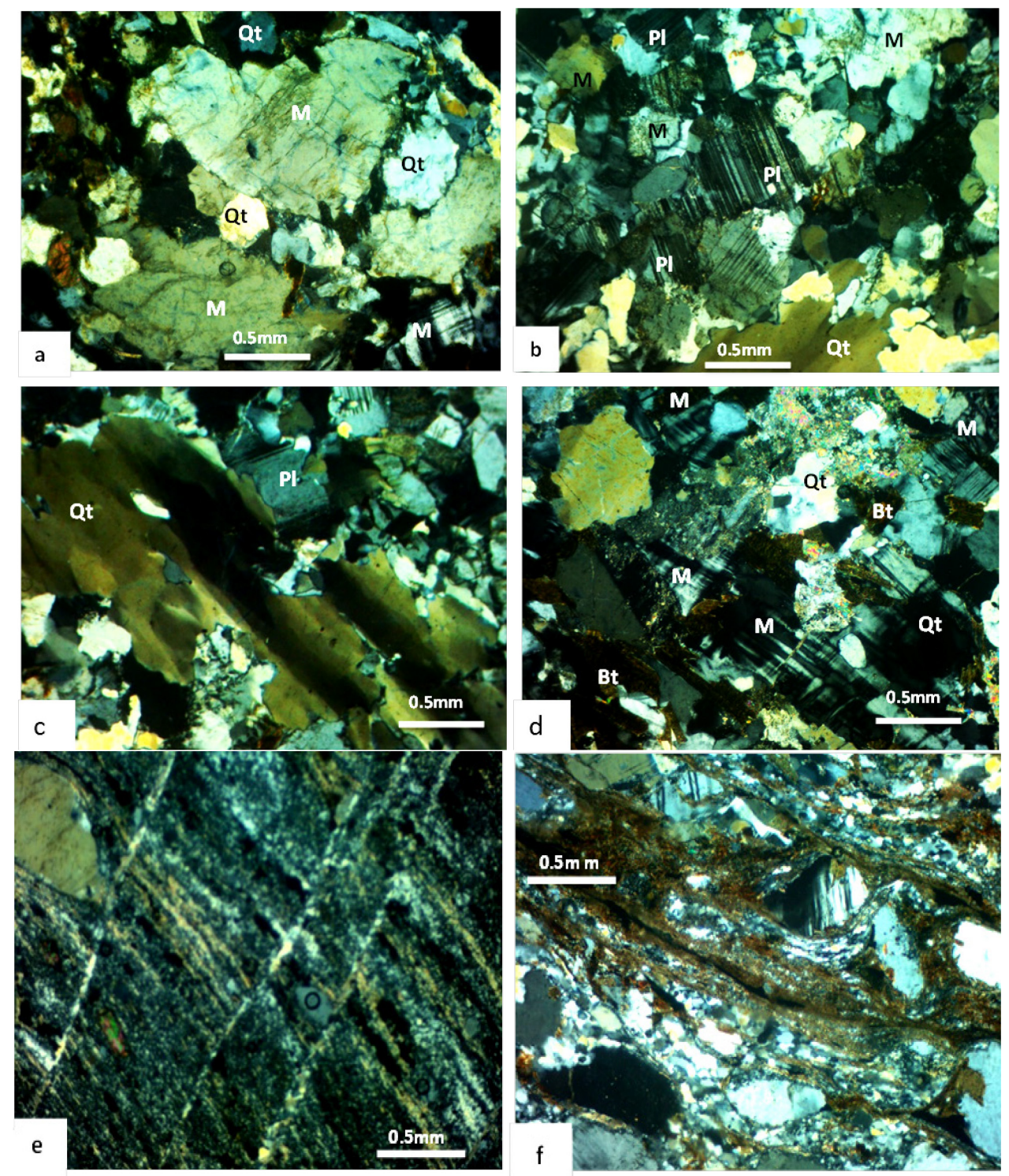

Fig. 5. Photomicrographs of selected thin sections of granitic gneiss showing dominant mineralogy (crossed polars) (a) mineralogy of the granitic gneiss adjacent to the shear zone (b) medium-grained texture of the granitic gneiss at the Oke-Odo quarry (c) undulose extinction in a quartz porphyroblast (d) weakly preferred orientation of biotite in the granitic gneiss. (e) ultramylonitic shear fabric in the strongly sheared granitic gneiss in Iwaraja locality (f) mylonitic kinematic indicator showing dextral sense shear fabric in the eastern domain in the strongly sheared granitic gneiss at Osinko. Note: M-microcline, Pl- plagioclase, Qt- quartz, Bt-biotite. 

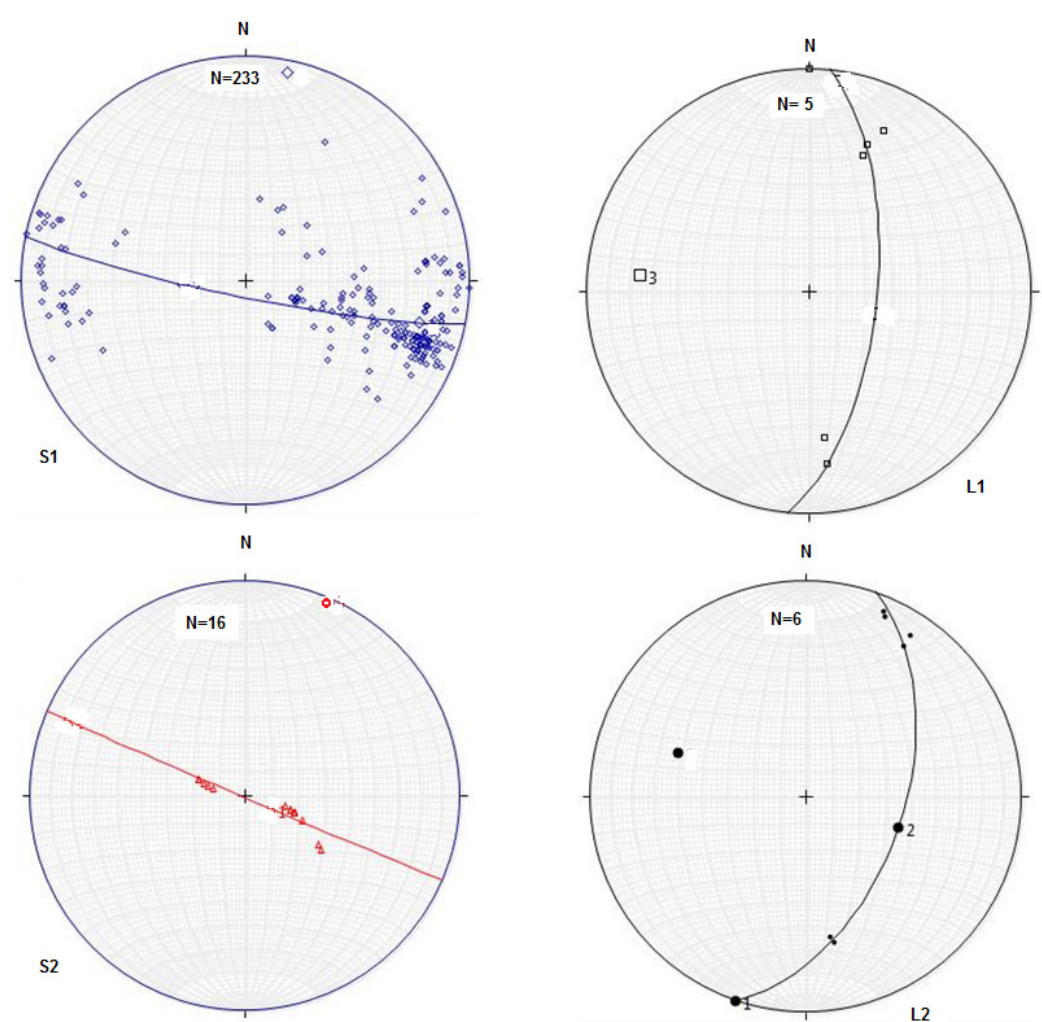

Fig. 6. Equal area stereographic projections plot of $\left(\mathrm{S}_{1}\right)$ foliation indicates that the fold axis plunges $06^{\circ}$ and trends $011^{\circ}$. The wide scattering of plot of poles shows polyphase deformation. Plot of lineations $\left(\mathrm{L}_{1}\right)$ outside the shear zone depicts a moderately plunging lineation. The plot of $\left(\mathrm{S}_{2}\right)$ foliation shows that the major fold axis plunges $02^{\circ}$ and trends $023^{\circ .}$ The orientations of the rock attitudes (strike and dip) with major density towards the center show a steeply dipping foliation surface $\left(\mathrm{S}_{2}\right)$. Plot of lineation $\left(\mathrm{L}_{2}\right)$ within the shear zone shows a shallowly plunging lineation and rotation during the second deformation.

\section{Discussion}

The metamorphic characters of the various lithological units from field and structural relationships showed that the migmatitic gneiss represent the oldest. This migmatitic gneiss has been described severally as Archaean basement [4,6] known in the Ilesha schist belt. Intrusive igneous processes and orogenesis that affected the initial sediments is believed to have metamorphosed the sediments to the present metasediments. Available geochronological records and lithostratigraphic classification show that the granitic gneiss, which have been variously referred to as orthogneisses in some literatures [6] yielded an age of ca. $1850 \mathrm{Ma}$ (upper intercept) by the U-Pb method on zircon. In the Ilesha schist belt, the metasediments are believed to overlie the orthogneisses $[3,4,6]$ although this overlying relationship was not observed within the study area. Also the description of the metasedimentary rocks in this study provided a distinction for the petrographic classification of the various lithological units described as Effon Psammite in [3]. 

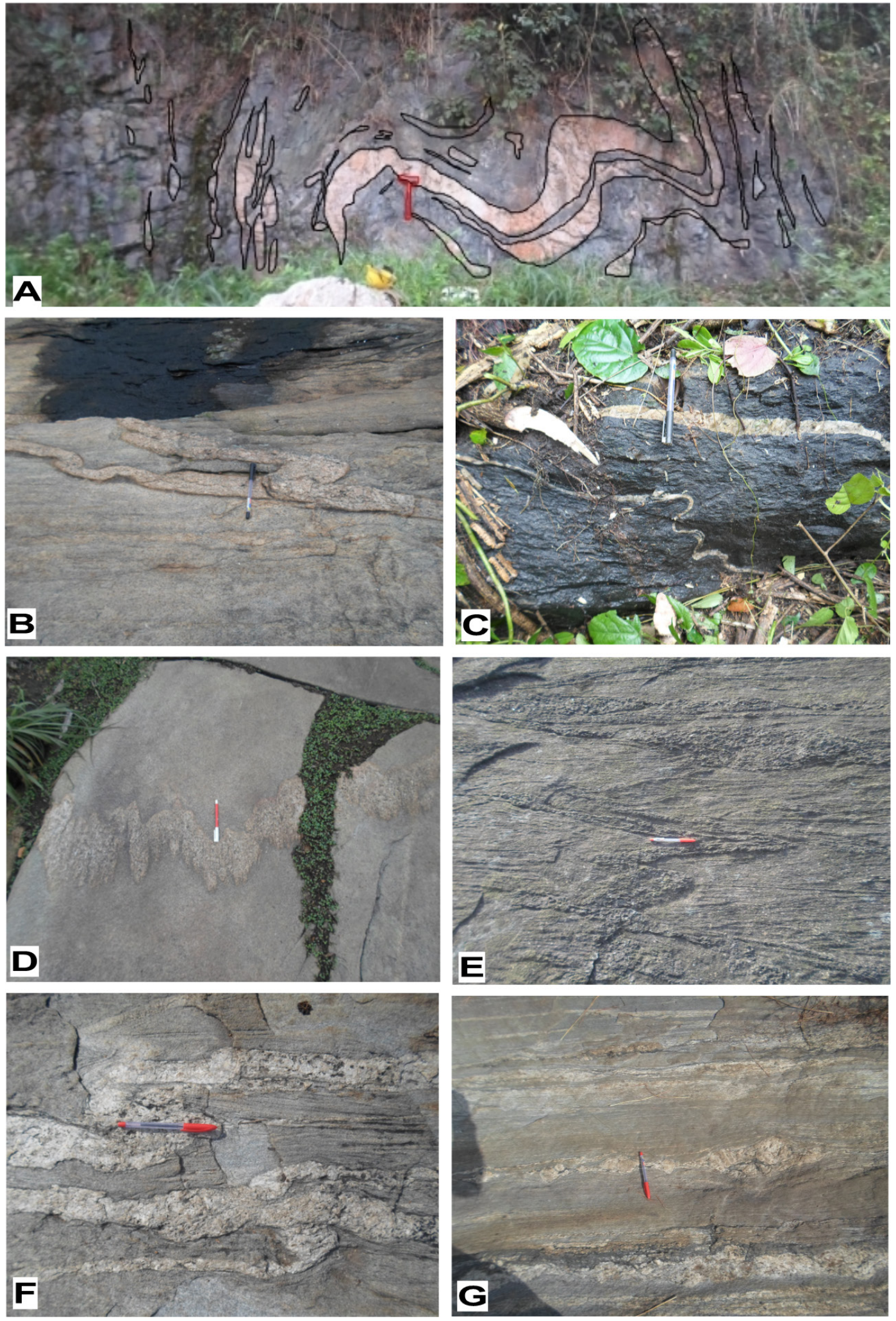

Fig. 7. Second phase deformation folds (a) open, asymmetrical fold of pegmatite dyke. The eastern flank is marked by sub-vertical tight fold of pegmatite dykes indicating progressive fold development. The migmatitic gneiss (b) and (d) is marked by intrafolial and ptygmatic folds of pegmatite dyke respectively (c) asymmetrical, open fold of quartz veins in biotite schist at OmoAiyegunle (e) asymmetrical, close to tight folds of deformed $\mathrm{S}_{1}$ fabric, (f) asymmetrical, tight minor folds $(\mathrm{g})$ boudinage of quartzo-feldspathic bands formed by extensional strain in the granitic around Idado localities. 


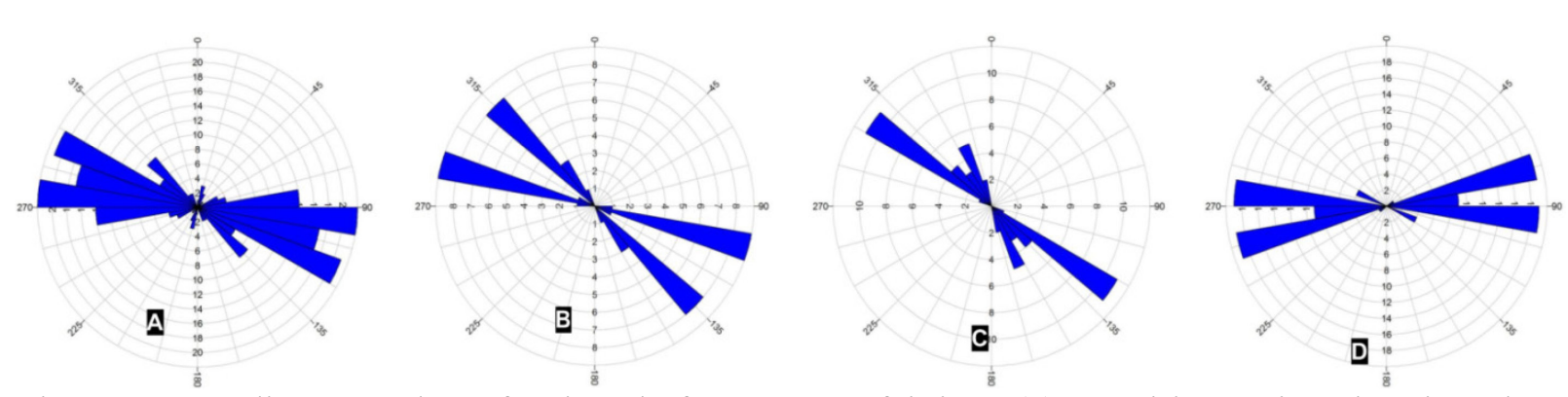

Fig. 8. Rose diagram plot of azimuth frequency of joints (a) granitic gneiss showing dominant WNW - ESE orientation (b) quartzite showing bimodal orientation of ENE - WSW and ESE WNW (c) quartz schist showing bimodal orientation of NW - SE and WNW - ESE (d) quartz-mica schist showing NW - SE orientation.

The first phase deformation $\left(D_{1}\right)$ is believed to be a fabric forming event because no minor fold of this phase was recognised in the study area. In several studies [e.g. 19, 20], ductile shear zones and early to late tight to isoclinal folds have been identified as dominant features associated with the internal zones of orogenic belts. These structures were observed and were commonly developed during the second deformation phase in the study area. These structures reflect the characteristic differences in the rheological responses of the affected rocks as a result of variations in strain gradients and progressive deformation during the localized second deformation phase. The existence of these structural features in the internal zones of orogenic belts has been documented from other parts of southwestern Nigeria [e.g. 21-23]. Shear zone folds of a pegmatite dyke associated with the second phase deformation $\left(D_{2}\right)$ vary from early to late tight to isoclinal folds. These kinds of folds are attributable to non-coaxial deformation associated with progressive simple shear [23]-[25]. Extensional fractures (joints) in the various outcrops generally show approximately bimodal orientations in the E-W and ESE-WNW directions in approximately oblique and perpendicular relationship to the regional metamorphic foliations. These orientations are similar to the orientations obtained in the works of [26]. It is believed that their orientations control gold mineralization in the mineralized zones of the western part of Ilesha schist belt.

\section{Conclusion}

The structural development in the Iwaraja area showed that the earliest deformation phase was mainly a fabric forming event, followed by the evolution and localization of a steeply-dipping, subvertical ductile shear zone which is coeval with the development of folds of quartzo-feldspathic veins and pegmatite dykes within and outside the ductile shear zone. The ductile shear zone commonly identified as the Iwaraja shear zone represents one of the most distinct manifestations of late-Precambrian deformation in southwestern Nigeria. The structural developments as discussed in this paper represent imprints of late-Precambrian deformation during the closing stages of PanAfrican orogeny, which is correlatable with those in the central Hoggar, Algeria within the TransSaharan mobile belt.

\section{References}

[1] F.H. Hubbard, Precambrian crustal development in western Nigeria: indications from the Iwo region, Geological Society of America Bulletin. 86 (1975) 548-564

[2] A.A. Elueze, Geology of the precambrian schist belt in Ilesha area, southwestern Nigeria. In: P.O. Oluyide et al., (Eds.), Precambrian geology of Nigeria, Geological Survey of Nigeria, (1988) 77-82.

[3] I.B. Odeyemi, A comparative study of remote sensing images of the structure of the Okemesi fold belt, Nigeria, ITC Netherlands Journal. (1993) 77-81

[4] R. Caby, J.M. Boesse, Pan-African Nappe System in Southwest Nigeria: The Ife-Ilesha Schist Belt, Journal of African Earth Sciences. 33 (2001) 211-225. 
[5] V.M. Oversby, Lead isotope study of aplites from the Precambrian rocks near Ibadan, south western, Nigeria, Earth Planetary Science Letters. 27 (1975) 177-180.

[6] M.A. Rahaman, Recent advances in the study of the basement complex of Nigeria. In: P.O. Oluyide et al., (Eds.), Precambrian geology of Nigeria, Geological Survey of Nigeria. (1988) 21-41.

[7] C.T. Okonkwo, V.Y. Ganev, U-Pb Geochronology of the Jebba granitic gneiss and its implications for the paleoproterozoic evolution of Jebba area, southwestern Nigeria, International Journal of Geosciences. 3 (2012) 1065-1073

[8] C.T. Okonkwo, V.Y. Ganev, Geochemistry and geochronology of orthogneisses in Bode Saadu area, southwestern Nigeria and their implications for the palaeoproterozoic evolution of the area, Journal of African Earth Sciences. 109 (2015) 131-142

[9] O. Van-Breemen, R. Pidgeon, P. Bowden, Age and isotopic studies of Pan-African granites from north-central Nigeria, Precambrian Research. 4 (1977) 301-319.

[10] W.R. Fitches et al., Late-Proterozoic schist belts and plutonism in NW Nigeria, Journal of Geological Society of London. 142 (1985) 319-337.

[11] R. Caby, Precambrian terranes of Benin- Nigeria and northeast Brazil and the late Proterozoic south Atlantic fit, Geological Society of America Special paper. 230 (1989)145-158.

[12] R. Caby, Terrane assembly and geodynamic evolution of central-western Hoggar: a synthesis, Journal of African Earth Sciences. 37 (2003) 133-159.

[13] E. Ferre, G. Gleizes, R. Caby, Obliquely convergent tectonics and granite emplacement in the Trans-Saharan belt of eastern Nigeria: a synthesis, Precambrian Research, 114 (2002)199219.

[14] R. Black et al., Outline of the Pan-African geology of Adrar des Iforas (rep. of Mall), Geol. Rundsch. 68(2) (1979) 543-564

[15] A. Kroner, R.J. Stern, Pan African Orogeny. In: R.C. Selley, L.R.M. Cocks, R.I. Plimer (Eds.), Encyclopedia of Geology. 1 (2005) 1-12

[16] K.C. Burke, J.F. Dewey, Orogeny in Africa. In: T.F.J. Dessauvagie A.J. Whiteman, (Eds.) African Geology, University of Ibadan. (1972) 583-608

[17] R. Caby, J.M.L. Bertrand, R. Black, Pan-African Ocean Closure and Continental Collision in the Hoggar-Iforas segment. Central Sahara, in Precambrian Plate Tectonics. A.Kroner (ed.) Elsevier Amsterdam, 1981, pp. 407-434

[18] B. Adeoti, Structural evolution of the basement complex rocks in Iwaraja area, southwestern Nigeria. unpublished master of technology thesis, Federal University of Technology, Akure, 2015.

[19] G.I. Alsop, R.E. Holdsworth, Shear zones - an introduction and overview. In: G. I. Alsop, R. E. Holdsworth, K. J. W. Mccaffrey, M. Hand, (Eds.), Flow Processes in Faults and Shear Zones. Geological Society, London, Special Publications. 224 (2004) 1-9

[20] J. Carreras, E. Druguet, A. Griera, Shear zone-related folds, Journal of Structural Geology. 27 (2005) 1229-1251

[21] J.M. Boesse, O.O. Ocan, M.A. Rahaman, Lithology and the structure of the Ife-Ilesha area (abstract), 25th Annual Conf. Nig. Mining and Geosc. Soc. (1989) 6-7.

[22] C.T. Okonkwo, Early recumbent folding and thrusting in the Jebba area, S.W. Nigeria (abstract), 32 ${ }^{\text {nd }}$ Annual Conf. Nig. Mining and Geosc. Soc. (1996) 77.

[23] C.T. Okonkwo, Structural evolution of bode Saadu area, Southwestern Nigeria African, Journal of Science and Technology. 2(2) (2001) 17-24.

[24] G.I. Alsop, Relationships between distributed and localized shear in the tectonic evolution of a caledonian fold and thrust zone, northwest Ireland, Geol. Mag. 131 (1994) 123-136.

[25] J.G. Ramsay, M. Casey, R. Kligfield, Role of shear in development of helvetic fold-thrust belt of Switzerland, Geology. 11 (1983) 439-442.

[26] A.Y.B. Anifowose, I.B. Odeyemi, A.M. Borode, The tectonic significance of the IfewaraZungeru megastructure in Nigeria, Proceedings of the 1st international workshop on geodesy and geodynamics center for geodesy and geodynamics, Toro, Nigeria. (2007) 17-28. 